\title{
Maturation of Viral Proteins in Cells Infected with Temperature-Sensitive Mutants of Vesicular Stomatitis Virus
}

\author{
DAVID M. KNIPE, ${ }^{1}$ DAVID BALTIMORE,* AND HARVEY F. LODISH \\ Department of Biology, Massachusetts Institute of Technology, Cambridge, Massachusetts 02139
}

Received for publication 10 September 1976

\begin{abstract}
Maturation of viral proteins in cells infected with mutants of vesicular stomatitis virus was studied by surface iodination and cell fractionation. The movement of $\mathrm{G}, \mathbf{M}$, and $\mathrm{N}$ proteins to the virion bud appeared to be interdependent. Mutations thought to be in $G$ protein prevented its migration to the cell surface, allowed neither $\mathrm{M}$ nor $\mathrm{N}$ protein to become membrane bound, and blocked formation of viral particles. Mutant G protein appeared not to leave the endoplasmic reticulum at the nonpermissive temperature, but this defect was partially reversible. In cells infected with mutants that caused $\mathrm{N}$ protein to be degraded rapidly or prevented its assembly into nucleocapsids, $\mathbf{M}$ protein did not bind to membranes and $\mathrm{G}$ protein matured to the cell surface, but never entered structures with the density of virions. Mutations causing $\mathbf{M}$ protein to be degraded prevented virion formation, and $\mathrm{G}$ protein behaved as in cells infected by mutants in $\mathrm{N}$ protein. These results are consistent with a model of virion formation involving coalescence of soluble nucleocapsid and soluble $\mathrm{M}$ protein with $\mathrm{G}$ protein already in the plasma membrane.
\end{abstract}

The pathways of maturation of the major structural proteins of vesicular stomatitis virus (VSV) have been characterized (5). The glycoprotein $(G)$ is both inserted into the membrane of the endoplasmic reticulum and partially glycosylated so rapidly that intermediates are not evident. The final stages of glycosylation occur after the $G$ protein has migrated to light-density membranes; soon thereafter it appears on the surface of the cell. At early times after its synthesis, the $\mathbf{M}$ protein is soluble; from this state it is progressively incorporated into membranous structures with the density of virions and then quickly appears in extracellular virions. The nucleocapsid $(\mathrm{N})$ protein is also soluble after its synthesis and is later incorporated into nucleocapsids that attach to the membrane prior to budding into extracellular virions.

Temperature-sensitive mutants of VSV have been isolated by several laboratories $(1,2,4,10$, 11 ), and mutants in some of the complementation classes have been shown to be defective in certain major structural proteins (7-9). To characterize the effects of these mutations on morphogenesis of virions, we have examined the virus-specific structures that accumulate in cells infected with these temperature-sensitive mutants at the nonpermissive temperature.

1 Present address: Committee on Virology, University of Chicago, Chicago, IL 60637.

\section{MATERIALS AND METHODS}

The origin and growth of the virus strains, cell fractionation, lactoperoxidase-catalyzed iodination of the cells, and other methods used in this paper have been described previously (5-7).

\section{RESULTS}

Migration of the G protein to the surface of cells infected with temperature-sensitive mutants. It was previously shown that the G protein of $t s \mathrm{M} 501$ (V) did not appear to undergo the final step(s) of glycosylation because the electrophoretic mobility of the protein did not decrease during a chase period (7). This change in mobility has been shown to involve the addition of sialic acid residues to the molecule several minutes prior to its appearance on the cell surface (6). We therefore tested whether the protein encoded by the mutant virus migrated to the surface of infected cells. This was tested in two ways, i.e., surface iodination with lactoperoxidase and protease treatment of $\left[{ }^{35} \mathrm{~S}\right]$ methionine-labeled cells.

(i) Iodination. The surface proteins of mockinfected Chinese hamster ovary cells labeled by lactoperoxidase-catalyzed iodination showed a pattern similar to that observed previously, except that in this case some labeled protein, migrating with bovine serum albumin and slightly slower than the VSV G marker, was 
observed (Fig. 1). This was presumably the result of the serum protein sticking to the cells. In the cells infected with wild-type virus, a new iodinated protein comigrating with virion G was observed on the surface of the cells under all infection conditions (see the legend to Fig. 1 for an explanation of infection conditions), and the greatest amount was present on cells kept continuously at $39^{\circ} \mathrm{C}$.

Iodination of cells infected with ts M301(III) at either 39 or $31^{\circ} \mathrm{C}$ revealed the presence of $\mathrm{G}$ protein on the surface of the cells, but with a greater amount at $39^{\circ} \mathrm{C}$ than at $31^{\circ} \mathrm{C}$ (Fig. 1). These results indicated that in cells infected at the nonpermissive temperature with a virus having an apparent mutation in the $M$ protein, the $G$ protein matured normally to the surface of the cells. It is of interest to note that the G protein on the surface of cells infected with ts M301(III) at either 39 or $31^{\circ} \mathrm{C}$ did not comigrate with the wild-type $\mathrm{G}$ protein, but migrated more slowly. This was previously observed with $\left.{ }^{35} \mathrm{~S}\right]$ methionine-labeled proteins and is probably due to differences between our wild-type VSV and the parent of mutant $t s \mathrm{M} 301$ (III) (7).

The mutant $t s \mathrm{O} 45$, a group $\mathrm{V}$ mutant which, like $t s \mathrm{M} 501(\mathrm{~V})$, encodes a $\mathrm{G}$ protein which remains underglycosylated at $39^{\circ} \mathrm{C}$ (data not shown), was previously shown to be defective in maturation of the $\mathrm{G}$ protein from dense membranes to light membranes (8). We observed no $\mathrm{G}$ protein on the surface of cells infected at $39^{\circ} \mathrm{C}$ with $t s \mathrm{O} 45(\mathrm{~V})$, but cells infected at $31^{\circ} \mathrm{C}$ showed a considerable amount (Fig. 1). Moreover, when cells infected at $39^{\circ} \mathrm{C}$ were shifted to $31^{\circ} \mathrm{C}$ for only $1 \mathrm{~h}$, a significant amount of $\mathrm{G}$ protein accumulated on the surface of the cells,

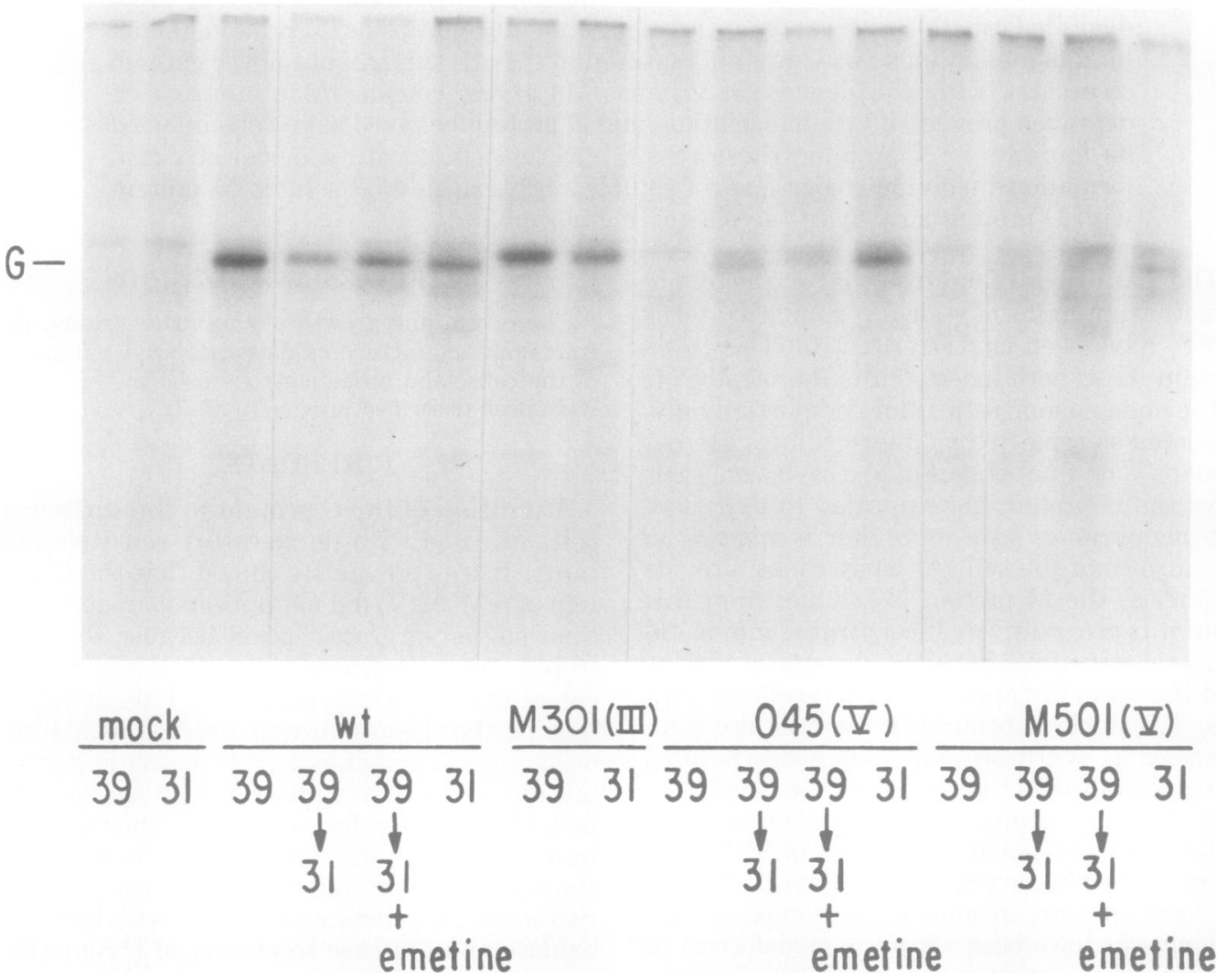

Fig. 1. Surface iodination of cells infected with temperature-sensitive mutants. Cells were infected with the indicated virus strain at a multiplicity of 10. At the termination of the infection, the cells were washed and iodinated as described in the text. The total cellular proteins were subjected to sodium dodecyl sulfatepolyacrylamide gel electrophoresis. Protocol for infections: $39^{\circ} \mathrm{C}$, entire infection at $39^{\circ} \mathrm{C}-c e l l s$ were harvested at $5 \mathrm{~h}$ postinfection; $31^{\circ} \mathrm{C}$, entire infection at $31^{\circ} \mathrm{C}$-cells were harvested at $5 \mathrm{~h}$ postinfection; $39^{\circ} \mathrm{C} \rightarrow 31^{\circ} \mathrm{C}$, infection at $39^{\circ} \mathrm{C}$ for the first $4 \mathrm{~h}$ of infection and then shifted to $31^{\circ} \mathrm{C}$ for $1 \mathrm{~h}$ of incubation; $39^{\circ} \mathrm{C} \rightarrow 31^{\circ} \mathrm{C}+$ emetine, infection at $39^{\circ} \mathrm{C}$ for the first $4 \mathrm{~h}$ of infection and then shifted to $31^{\circ} \mathrm{C}$ for $1 \mathrm{~h}$ of incubation in the presence of $20 \mu \mathrm{g}$ of emetine per $\mathrm{ml}$ (exposure time, $48 \mathrm{~h}$ ). 
showing that the defect was partially reversible. The appearance of $\mathrm{G}$ on the surface also occurred in the presence of $20 \mu \mathrm{g}$ of emetine per $\mathrm{ml}$, a concentration sufficient to abolish all virus protein synthesis. Hence, some of the $G$ protein previously synthesized at $39^{\circ} \mathrm{C}$, but blocked in maturation within the cell, could move to the surface of the cell once the temperature was lowered.

In addition, no labeled $G$ protein could be found on the surface of cells infected with $t s \mathrm{M} 501(\mathrm{~V})$ at $39^{\circ} \mathrm{C}$, whereas at $31^{\circ} \mathrm{C}$ there was a detectable amount of $G$ protein on the surface (Fig. 1). A small amount of $G$ protein could be detected on the surface of cells within $1 \mathrm{~h}$ after cells, growing at $39^{\circ} \mathrm{C}$, were shifted to $31^{\circ} \mathrm{C}$. This appearance also occurred in the absence of protein synthesis, indicating that the defect was partially reversible. The increased label in the bands of the sample with emetine was probably due to a darker background because it was not apparent in other experiments. Thus, we conclude that these two group $\mathrm{V}$ mutants are defective in maturation of the $\mathrm{G}$ protein to the surface of infected cells at the nonpermissive temperature.

(ii) Protease treatment. To corroborate the findings with lactoperoxidase labeling, we treated intact, infected cells with chymotrypsin to assay for the presence of the $G$ protein on the cell surface. Infected cells were labeled with $\left[{ }^{35} \mathrm{~S}\right]$ methionine for $15 \mathrm{~min}$ and then incubated for an additional $60 \mathrm{~min}$ after the addition of excess unlabeled methionine. The infected cells were then treated with chymotrypsin and prepared for gel electrophoresis. After a 60-min chase period, the $\mathrm{G}$ protein labeled at 39 or $31^{\circ} \mathrm{C}$ in cells infected with wild-type VSV was largely sensitive to pratease treatment and thus was on the surface of the cells (Fig. 2).

The $\mathrm{G}$ protein labeled at $39^{\circ} \mathrm{C}$ in cells infected with $t s \mathrm{M} 501(\mathrm{~V})$ was not susceptible to protease treatment and thus not on the surface of the cells. As evidenced by its protease sensitivity, it was present on the surface of the cells at $31^{\circ} \mathrm{C}$. This confirmed the conclusion from the iodina- w† VSV

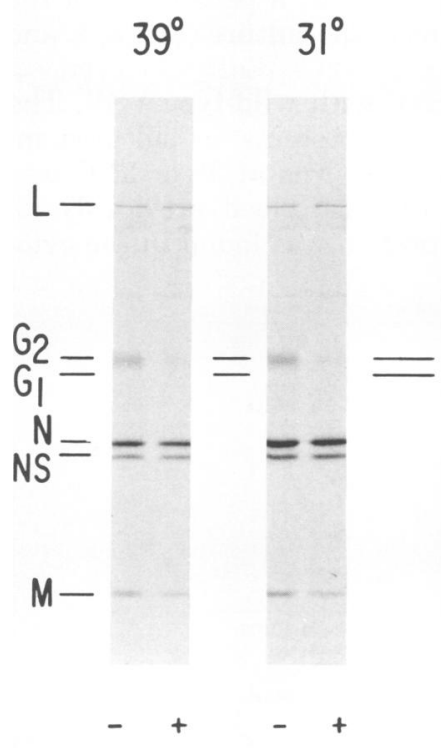

ts $M 501(\nabla)$

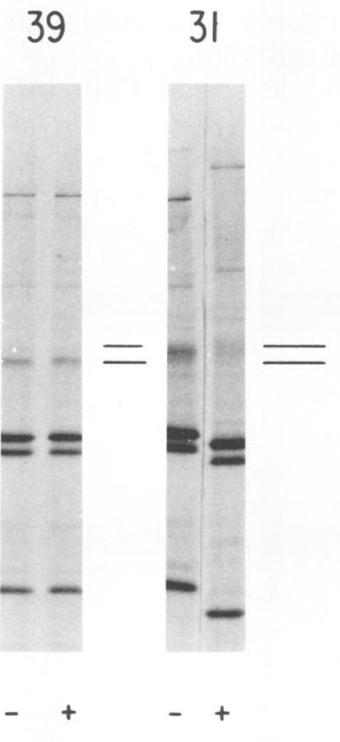

†sM 301(III)

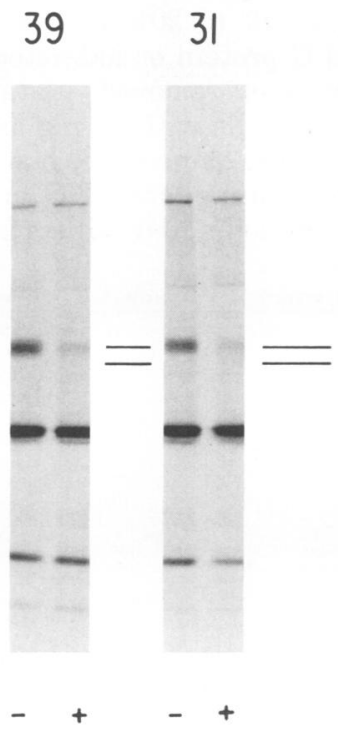

†sM 601 (ZI)

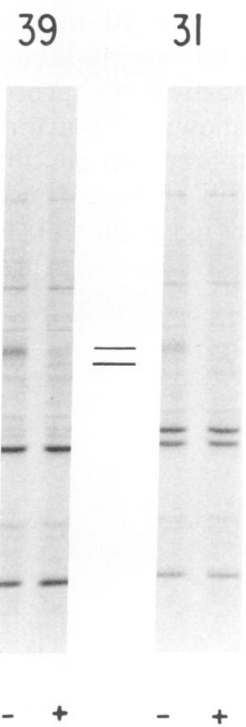

\section{Chymotrypsin treałment}

FIg. 2. Protease treatment of intact cells infected with temperature-sensitive mutants of VSV.Cultures were infected with the indicated virus strain at a multiplicity of 10 and incubated at $31^{\circ} \mathrm{C}$ for $5 \mathrm{~h}$. At that time the cells were resuspended in complete medium lacking methionine, and one-half of them were placed at $39^{\circ} \mathrm{C}$ and the remainder were placed at $31^{\circ} \mathrm{C}$. After a 10-min warming period, the cultures were labeled for 15 min with $\left[{ }^{35} \mathrm{~S}\right.$ ] methionine. The cultures were then incubated with excess unlabeled methionine for $60 \mathrm{~min}$. The cells were washed and treated with chymotrypsin $\left(1 \mathrm{mg}\right.$ of chymotrypsin per $\mathrm{ml}$ for $10 \mathrm{~min}$ at $37^{\circ} \mathrm{C}$, except for tsM301(III), which was treated with $10 \mathrm{mg}$ of chymotrypsin per $\mathrm{ml}$ ). Exposure times: wt, $24 \mathrm{~h} ; \mathrm{tsM501(V),72}$ $h$; tsM301(III), $24 h$; tsM601(VI), $24 h$. 
tion results that the $G$ protein encoded by $t s \mathrm{M} 501(\mathrm{~V})$ did not mature properly to the surface of the cells at $39^{\circ} \mathrm{C}$.

This technique was also applied to cells infected with temperature-sensitive mutants that were defective in RNA synthesis at the nonpermissive temperature. RNA synthesis was allowed to proceed at $31^{\circ} \mathrm{C}$, and the culture was then shifted to $39^{\circ} \mathrm{C}$ prior to labeling with $\left.{ }^{[35} \mathrm{S}\right]$ methionine. Thus, all of the labeled $\mathrm{G}$ protein would be synthesized and mature at the nonpermissive temperature. In contrast, surface iodination would not distinguish newly synthesized $G$ protein from $G$ protein put on the surface prior to the temperature shift. In cells infected with $t s \mathrm{M} 601(\mathrm{VI})$ at $39^{\circ} \mathrm{C}$, a large percentage of the $\mathrm{G}$ protein was removed by protease treatment and thus was on the surface of the cells. Because replication of viral RNA is low in these cells at $39^{\circ} \mathrm{C}$ and also the $\mathrm{N}$ protein is degraded rapidly (7), there could be at most a small pool of nucleocapsids in these cells at $39^{\circ} \mathrm{C}$. Therefore, it appears probable that nucleocapsids have little role in maturation of the $\mathrm{G}$ protein to the surface of cells.

When cells infected with $t s$ M301(III) at 39 or $31^{\circ} \mathrm{C}$ were exposed to $1 \mathrm{mg}$ of chymotrypsin per $\mathrm{ml}$ for $10 \mathrm{~min}$, only 10 to $20 \%$ of the $\left.{ }^{[35} \mathrm{S}\right]-$ methionine-labeled $G$ protein or iodinated cell surface $G$ protein was removed (data not shown). Treatment of cells with $10 \mathrm{mg}$ of chymotrypsin per $\mathrm{ml}$ for the same time, however, did remove $\left.{ }^{35} \mathrm{~S}\right]$ methionine-labeled $\mathrm{G}$ protein (Fig. 2) as well as the iodinated cell surface $G$ protein (data not shown). Removal of the $G$ protein from cells infected by the Glasgow strains of VSV also required $10 \mathrm{mg}$ of enzyme per ml, suggesting that the parent of ts M301(III) is the Glasgow strain and supporting the previous conclusion that $t s$ M301(III) is the same mutant as $t s$ G33(III). Using the higher enzyme concentration, it is apparent that a mutation of the $M$ protein gene does not affect movement of the $G$ protein to the cell surface.

Fractionation of cells infected with temperature-sensitive mutants. To examine the effects of various mutations on the maturation of the nonmutant proteins, we utilized the fractionation procedure described previously (5). Cells were infected with wild-type and temperature-sensitive mutant strains of virus, labeled with [ $\left.{ }^{35} \mathrm{~S}\right]$ methionine for $30 \mathrm{~min}$ at $5 \mathrm{~h}$ postinfection, and subjected to chase conditions for 30 min at the permissive or nonpermissive temperature.

The proteins from each subcellular fraction were recovered and subjected to sodium dodecyl sulfate-polyacrylamide gel electrophoresis. The amount of each viral protein in each subcellular fraction was expressed as a percentage of the total viral proteins in the culture (Fig. 3,4 , and 5).

(i) Cells infected with wild-type VSV. The distribution of viral proteins in cultures infected with wild-type virus at 39 or $31^{\circ} \mathrm{C}$ was very similar to that described previously (5) (Fig. 3). The M protein was found in the cyto-

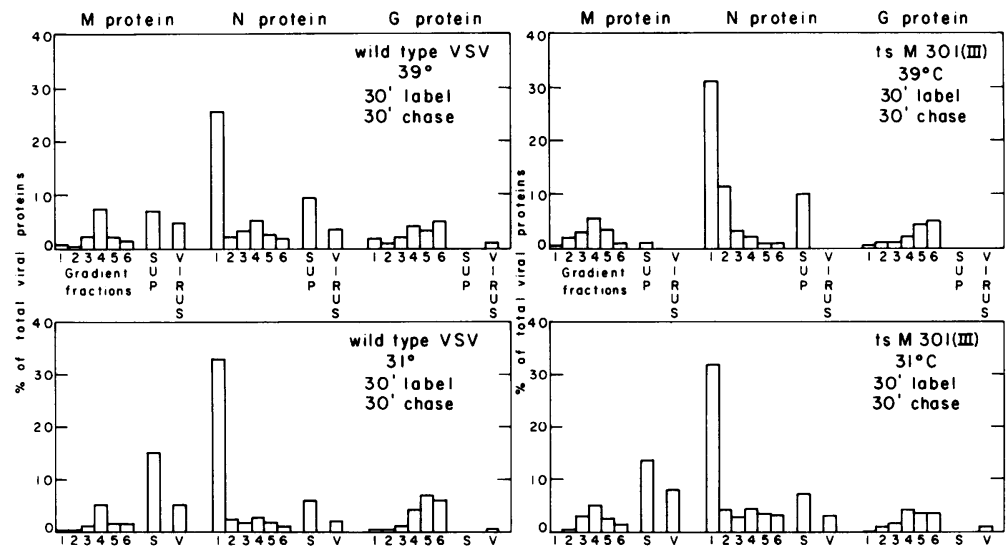

FIG. 3. Fractionation of cells infected with temperature-sensitive mutants of VSV: wild-type and tsM301(III) protein distributions. Cultures were infected with the indicated virus strain at a multiplicity of 10 at 39 or $31^{\circ} \mathrm{C}$. At $5 \mathrm{~h}$ postinfection the cells were resuspended in complete medium lacking methionine and labeled for 30 min. Excess unlabeled methionine was added and incubation was continued for 30 min. The cells were then fractionated by the procedure described by Knipe et al. (5), with the use of $0.1 \mathrm{M} \mathrm{NaCl}$ in the initial centrifugation to eliminate $M$ aggregation. The proteins were recovered from each subcellular fraction and subjected to sodium dodecyl sulfate-polyacrylamide gel electrophoresis. The amount of each protein in each fraction was determined and expressed as a percentage of the total amount of viral proteins in the culture. 


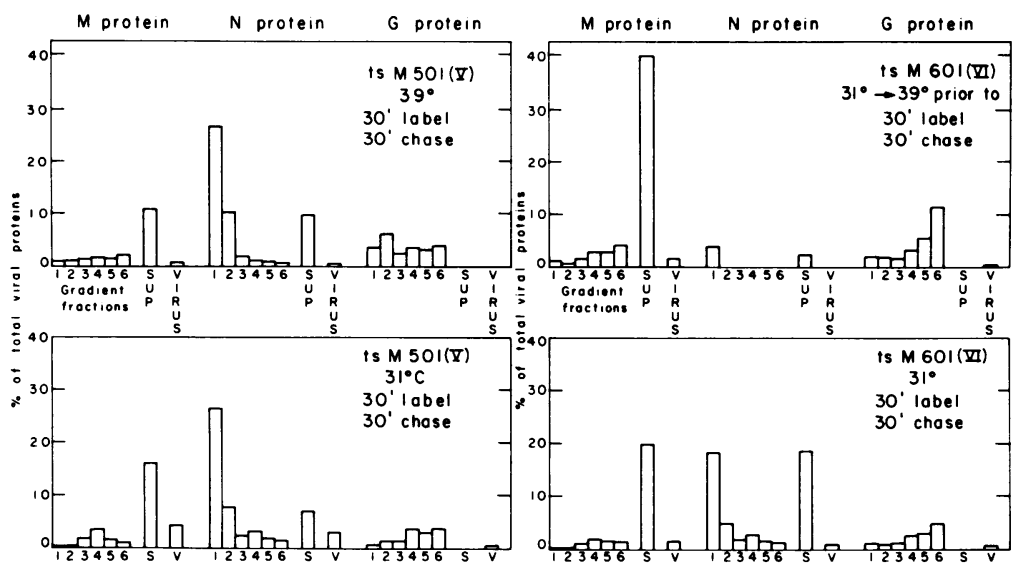

FIG. 4. Fractionation of cells infected with temperature-sensitive mutants of VSV: tsM501(V) and tsM601(VI). These experiments were performed as described in the legend to Fig. 2, except that cells infected with tsM501(V) and tsM601(VI) were used. The culture infected with tsM601(VI), which was labeled at $39^{\circ} \mathrm{C}$, was incubated at $31^{\circ} \mathrm{C}$ for the first $5 \mathrm{~h}$ of infection and shifted to $39^{\circ} \mathrm{C} 10 \mathrm{~min}$ prior to labeling.

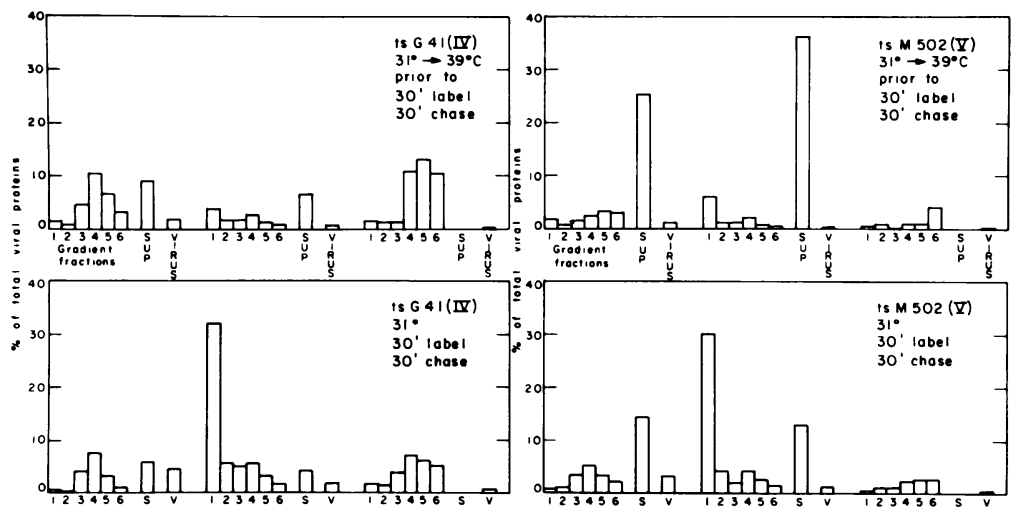

Fig. 5. Fractionation of cells infected with temperature-sensitive mutants of VSV: tsG41(IV) and tsM502(V). These experiments were performed as described in the legend to Fig. 2, except that cells infected with tsG41(IV) and tsM502(V) were used. The cultures labeled at $39^{\circ} \mathrm{C}$ were incubated at $31^{\circ} \mathrm{C}$ for the first $3 \mathrm{~h}$ of infection, and one-half were shifted to $39^{\circ} \mathrm{C}$ for $2 \mathrm{~h}$ of incubation prior to labeling at the appropriate temperatures.

plasmic supernatant and in a symmetrical distribution about fraction 4 of the isopycnic gradient. The membranous structures in fractions 3 and 4 that contain $M$ protein are believed to be newly budded virus attached to the cells and budding intermediates. The only difference between cultures infected at 39 and $31^{\circ} \mathrm{C}$ was the observation that the percentage of soluble $\mathbf{M}$ protein was twice as great at $31^{\circ} \mathrm{C}$ as at $39^{\circ} \mathrm{C}$, possibly the result of the increased degradation rate of the $\mathrm{M}$ protein at $39^{\circ} \mathrm{C}$ (7). The $\mathrm{N}$ protein was found largely in nucleocapsids in fraction 1 at both temperatures. $\mathrm{N}$ protein was also found in the cytoplasmic supernatant and in a second peak of $\mathrm{N}$ protein-containing structures centered around fraction 4 in the gradient membrane fractions. After this long chase period the
G protein is found mainly in the subcellular fractions enriched in plasma membranes, i.e., fractions 5 and 6 . There was also some G protein in fraction 4, presumably in virions attached to cells.

(ii) Mutations in the M protein. The distribution of viral proteins in cells infected with $t s \mathrm{M} 301$ (III) at $39^{\circ} \mathrm{C}$ showed that the $\mathrm{M}$ protein was found in similar fractions on the isopycnic gradient as in wild-type virus-infected cells, with a peak centered around fraction 4 (Fig. 3). However, there was very little M protein in the cytoplasmic supernatant, which may have been a result of the rapid degradation rate of the $M$ protein at $39^{\circ} \mathrm{C}(7)$. The $\mathrm{N}$ protein was found almost entirely in free nucleocapsids, and much less $\mathrm{N}$ protein floated, up into gradient fraction 
4 as compared with cells infected with wild-type virus at $39^{\circ} \mathrm{C}$ or $t s \mathrm{M} 301$ (III) at $31^{\circ} \mathrm{C}$. The $\mathrm{G}$ protein was found largely in fractions 5 and 6 , apparently in the plasma membrane, because of the previous experiments (5) demonstrating the sensitivity of the $G$ protein to protease treatment of intact cells. In addition, there were virtually no viral proteins found in extracellular virus particles produced by these cells. Thus, this mutation prevented the formation of physical virus particles as well as infectious virus. This was consistent with the observations of Unger and Reichmann (13), which showed that cells infected with $t s$ G31, another group III mutant, incorporated labeled RNA into nucleocapsids, but not into virus particles.

In cells infected with $t s \mathrm{M} 301$ (III) at $31^{\circ} \mathrm{C}$ the distributions of the viral proteins were very similar to those in cells infected with wild-type virus. Much more $\mathrm{M}$ protein was found in the cytoplasmic supernatant than at $39^{\circ} \mathrm{C}$, and much more $\mathrm{N}$ protein floated up with the membranes in the isopycnic gradient.

(iii) Mutations in the glycoprotein. In cells infected with $t s \mathrm{M} 501(\mathrm{~V})$ at $39^{\circ} \mathrm{C}$, we observed that the largest amount of $\mathrm{G}$ protein was in fractions 1 and 2, the fractions shown to be richest in endoplasmic reticulum (Fig. 4). Thus, the $\mathrm{G}$ protein may be defective in movement from the endoplasmic reticulum. Consistent with this observation are the findings that at $39^{\circ} \mathrm{C}$ only the $\mathrm{G}_{1}$ form of the glycoprotein was found and that none of the $G$ protein was found on the cell surface (Fig. 1 and 2). The $\mathrm{N}$ protein was found mainly in fractions 1 and 2 as free nucleocapsids. The $M$ protein was found largely in the cytoplasmic supernatant, with smaller amounts scattered across the density gradient. The amount of $M$ protein in the supernatant has varied from 55 to $67 \%$ in several experiments, whereas only 20 to $30 \%$ of the wild-type protein was present in the cell supernatant. Therefore, the presence of $G$ protein on the cell surface appears to have a role in the attachment of the $\mathrm{M}$ protein to membranes. At $31^{\circ} \mathrm{C}$ the $\mathrm{G}$ protein migrated normally to the plasma membrane fractions, and the $\mathrm{M}$ and $\mathrm{N}$ proteins were found in their normal distribution about fraction 4. Total labeled protein accumulation in extracellular virus was at least fivefold higher at $31^{\circ} \mathrm{C}$, indicating a defect in particle maturation at the nonpermissive temperature. Although the data are not shown, similar protein distributions have been observed for ts $\mathrm{O} 45(\mathrm{~V})$, a mutant having a similar defect in maturation of the $\mathrm{G}$ protein.

(iv) Mutations affecting the $\mathrm{N}$ protein. $\mathrm{Mu}$ tant $t s \mathrm{M} 601$ (VI) was shown to encode an $\mathrm{N}$ protein that degrades rapidly at $39^{\circ} \mathrm{C}$, and the mutant synthesizes little 40S viral RNA, even at $31^{\circ} \mathrm{C}(7)$. Since this mutant is defective in RNA synthesis, we allowed RNA synthesis at $31^{\circ} \mathrm{C}$ for $5 \mathrm{~h}$ and then shifted the culture to $39^{\circ} \mathrm{C}$ prior to labeling with $\left.{ }^{[35} \mathrm{S}\right]$ methionine. The amount of nucleocapsids in the cells was therefore determined by the size of the nucleocapsid pool at $31^{\circ} \mathrm{C}$. As expected, the amount of labeled $\mathrm{N}$ protein in the cells labeled at $39^{\circ} \mathrm{C}$ was very low due to its rapid degradation (Fig. 4). The G protein in these cells was found largely in the gradient fractions that contain plasma membrane (fractions 5 and 6 ). However, the $M$ protein was largely in the cell cytoplasmic supernatant, indicating that it cannot stably attach to membranes. The percentage of free $M$ ranged from 67 to $75 \%$, and the remainder of the $M$ protein was distributed across the gradient, with slightly larger amounts closer to the top of the gradient (fractions 5 and 6 ). At $31^{\circ} \mathrm{C}$ the $\mathrm{N}$ protein was partly in nucleocapsids, but, as compared with wild-type VSV, an unusually large proportion was in the cytoplasmic supernatant. This was not unexpected since the amount of viral RNA replication was low at $31^{\circ} \mathrm{C}$, but the $\mathrm{N}$ protein was stable. Thus, less $\mathrm{N}$ protein was bound to RNA in these cells. The amount of soluble $M$ was high, presumably due to the low rate of virus assembly because of the lack of nucleocapsids and the lower rate of $\mathbf{M}$ protein degradation at $31^{\circ} \mathrm{C}$.

Although the amount of viral proteins assembled into virus from cells infected with ts $\mathrm{M} 601$ (VI) and labeled at 39 or $31^{\circ} \mathrm{C}$ appears to be the same as that shown in Fig. 4, in absolute amounts the proteins at $31^{\circ} \mathrm{C}$ were two- to threefold higher due to the degradation of virtually all of the $\mathrm{N}$ protein and significant amounts of $\mathrm{M}$ protein at $39^{\circ} \mathrm{C}$. This made the percentages of viral proteins in extracellular particles at $39^{\circ} \mathrm{C}$ artificially high. We presume that cells infected with $t s \mathrm{M601}$ (VI) have a low level of intracellular nucleocapsids at $31^{\circ} \mathrm{C}$, which leads to the low level of virus formation observed.

In cells infected with $t s$ G41(IV) and labeled at $39^{\circ} \mathrm{C}$, a reduced amount of $\mathrm{N}$ protein was present in the cells due to its rapid degradation (Fig. 5). The undegraded $\mathrm{N}$ protein was found in low amounts in fraction 1, possibly in nucleocapsids, but much was in the cytoplasmic supernatant. The $\mathrm{G}$ protein was largely in fractions 5 and 6 and thus presumably in the plasma membranes. In contrast to cells infected with $t s \mathrm{M} 601$ (VI), a high percentage of the M protein and some $G$ protein were in membranous structures distributed about fraction 4 on the isopycnic gradient, with normal levels in the cytoplasmic supernatant. At $31^{\circ} \mathrm{C}$ a threeto fourfold-higher amount of viral proteins was 
incorporated into extracellular virus, and the distributions of the viral proteins were very similar to those of cells infected with our wildtype virus.

We have included in this section experiments describing the fractionation of cells infected with $t s \mathrm{M} 502(\mathrm{~V})$ because it is obvious from Fig. 5 that $t s \mathrm{M} 502(\mathrm{~V})$ has a defect affecting the assembly of $\mathrm{N}$ protein into nucleocapsids. In cells labeled at $39^{\circ} \mathrm{C}$ nearly all of the $\mathrm{N}$ protein was present in the cytoplasmic supernatant as well as most of the viral $M$ protein. Thus it appeared that the $M$ protein could not stably bind to membranes in these cells. The $\mathrm{G}$ protein migrated normally to fractions 5 and 6 , but seemed to represent a lower percentage of the total labeled viral proteins than normal at both this temperature and $31^{\circ} \mathrm{C}$. At $31^{\circ} \mathrm{C}$ a more normal distribution of viral proteins was observed, except that the amount of soluble $\mathrm{N}$ protein was still higher than wild type. This could mean that the defect is still partially manifest even at the permissive temperature. In spite of the fact that $t s \mathrm{M} 502(\mathrm{~V})$ was assigned to group $\mathrm{V}$ on genetic grounds, we have been unable to find any defect in the maturation of the $\mathrm{G}$ protein. The only apparent defect is lower levels of synthesis of $\mathrm{G}$ protein in some experiments.

Temperature-shift experiments of cultures infected with temperature-sensitive mutants. To explore whether the blocks to virion maturation defined above were reversible or not, we incubated infected cells for $3 \mathrm{~h}$ at $31^{\circ} \mathrm{C}$, followed by $2 \mathrm{~h}$ at $39^{\circ} \mathrm{C}$, and the cells were then labeled for $30 \mathrm{~min}$ at $39^{\circ} \mathrm{C}$ with $\left.{ }^{3{ }^{5}} \mathrm{~S}\right]$ methionine. The cultures were further incubated with excess unlabeled methionine for $30 \mathrm{~min}$. At that time one-half of each infected culture was removed and placed at 0 to $4^{\circ} \mathrm{C}$, and the remainder was shifted to $31^{\circ} \mathrm{C}$ for $1 \mathrm{~h}$. At that time the cells were harvested from the cultures and their cytoplasm was fractionated into a supernatant and a pellet of particulate material, prepared as in the previously described fractionation scheme. The only infected culture that incorporated a significant amount of labeled viral proteins into extracellular viral particles at $39^{\circ} \mathrm{C}$ was the culture infected with wild-type virus (Table 1). After the shift in temperature to $31^{\circ} \mathrm{C}$ the culture infected with wild-type virus released 2.5 times as much labeled protein in extracellular virions. However, many of the cultures infected with temperature-sensitive

TABLE 1. Effect of temperature shift on the subcellular location of proteins encoded by temperature-sensitive mutants ${ }^{a}$

\begin{tabular}{|c|c|c|c|c|c|c|c|c|c|}
\hline \multirow{3}{*}{ Wild type or mutant } & \multicolumn{9}{|c|}{$\%$ of total: } \\
\hline & \multicolumn{3}{|c|}{ M protein } & \multicolumn{3}{|c|}{$\mathrm{N}$ protein } & \multicolumn{3}{|c|}{ G protein } \\
\hline & $\begin{array}{l}\text { Cell pel- } \\
\text { let }\end{array}$ & $\begin{array}{c}\text { Cell su- } \\
\text { perna- } \\
\text { tant }\end{array}$ & Virus & $\begin{array}{l}\text { Cell pel- } \\
\text { let }\end{array}$ & $\begin{array}{c}\text { Cell su- } \\
\text { perna- } \\
\text { tant }\end{array}$ & Virus & $\begin{array}{l}\text { Cell pel- } \\
\text { let }\end{array}$ & $\begin{array}{c}\text { Cell su- } \\
\text { perna- } \\
\text { tant }\end{array}$ & Virus \\
\hline wt, $39^{\circ} \mathrm{C}$ & 38 & 18 & 44 & 69 & 12.5 & 18 & 90 & 0 & 10 \\
\hline wt, $39^{\circ} \mathrm{C} \rightarrow 31^{\circ} \mathrm{C}$ & 15 & 7 & 78 & 42 & 12 & 46 & 45 & & 45 \\
\hline$t s \mathrm{M} 301(\mathrm{III}), 39^{\circ} \mathrm{C}$ & 93 & 7 & 0 & 93 & 6 & 1 & 99.6 & 0 & 0.4 \\
\hline $\begin{array}{l}t s \mathrm{M} 301(\mathrm{III}), 39^{\circ} \mathrm{C} \rightarrow \\
\quad 31^{\circ} \mathrm{C}\end{array}$ & 95 & 0 & 5 & 76 & 13 & 10 & 88 & 0 & 12 \\
\hline$t s \mathrm{M} 501(\mathrm{~V}), 39^{\circ} \mathrm{C}$ & 29 & 71 & 0 & 81 & 19 & 0 & 100 & 0 & 0 \\
\hline $\begin{array}{l}t s \mathrm{M} 501(\mathrm{~V}), 39^{\circ} \mathrm{C} \rightarrow \\
\quad 31^{\circ} \mathrm{C}\end{array}$ & 54 & 42 & 4 & 90 & 6 & 4 & 100 & 0 & 0 \\
\hline$t s \mathrm{O} 45(\mathrm{~V}), 39^{\circ} \mathrm{C}$ & 49 & 51 & 0 & 19 & 28 & 3 & 100 & 0 & 0 \\
\hline $\begin{array}{l}t s \mathrm{O} 45(\mathrm{~V}), \quad 39^{\circ} \mathrm{C} \rightarrow \\
31^{\circ} \mathrm{C}\end{array}$ & 64 & 11 & 24 & 75 & 16 & 9 & 89 & 0 & 11 \\
\hline$t s \mathrm{M} 601(\mathrm{VI}), 39^{\circ} \mathrm{C}$ & 36 & 64 & 0 & 16 & 83 & 0 & 100 & 0 & 0 \\
\hline $\begin{array}{l}t s \mathrm{M} 601(\mathrm{VI}), 39^{\circ} \mathrm{C} \rightarrow \\
31^{\circ} \mathrm{C}\end{array}$ & 36 & 41 & 22 & 15 & 85 & 0 & 97 & 0 & 3 \\
\hline ts G41(IV), $39^{\circ} \mathrm{C}$ & 69 & 26 & 6 & 49 & 51 & 0.7 & 94 & 3 & 3 \\
\hline $\begin{array}{l}t s \mathrm{G} 41(\mathrm{IV}), 39^{\circ} \mathrm{C} \rightarrow \\
31^{\circ} \mathrm{C}\end{array}$ & 51 & 12 & 37 & 83 & 15 & 2 & 90 & 0 & 10 \\
\hline
\end{tabular}

${ }^{a}$ Cultures were infected with the indicated virus and incubated at $31^{\circ} \mathrm{C}$ for $3 \mathrm{~h}$. At that time the cultures were shifted to $39^{\circ} \mathrm{C}$ and further incubated for $2 \mathrm{~h}$. The cultures were labeled for 30 min with $\left[{ }^{35} \mathrm{~S}\right] \mathrm{methionine}$ and then incubated with excess unlabeled methionine for $30 \mathrm{~min}$. At that time one-half of the culture was removed and placed at 0 to $4^{\circ} \mathrm{C}$. The remainder was transferred to $31^{\circ} \mathrm{C}$ and incubation was continued for 60 min. The cells were fractionated into a cytoplasmic supernatant and a $100,000 \times g$ pellet of membranous and particulate material. Centrifugation was performed in the presence of $0.1 \mathrm{M} \mathrm{NaCl}$ to eliminate $\mathrm{M}$ protein aggregation. 
mutant virus showed a much more dramatic increase in the amount of viral proteins in extracellular virus, presumably due to a reversal of the temperature-sensitive defect.

In cells infected with $t s$ M301(III) the total amount of labeled viral proteins in virions increased approximately 20 -fold after shifting to $31^{\circ} \mathrm{C}$. The amount of $\mathrm{N}$ and $\mathrm{G}$ protein increased dramatically in extracellular virions after the shift-down in temperature, but very little of the $M$ protein that had not been degraded was chased into virus, a result first observed by Lafay (8) for $t s \mathrm{O} 89$ (III). Thus, M protein made at $39^{\circ} \mathrm{C}$ in cultures infected with $t s \mathrm{M} 301$ (III) was either in an aberrant structure or had an irreversible defect. In a similar experiment, the extracellular virus titer increased from $5 \times 10^{4}$ $\mathrm{PFU} / \mathrm{ml}$ in the $39^{\circ} \mathrm{C}$ culture to $8 \times 10^{6} \mathrm{PFU} / \mathrm{ml}$ in the infection shifted to $31^{\circ} \mathrm{C}$ for $1 \mathrm{~h}$. Thus, it appeared that infectious particles were produced after the shift in temperature, but little $\mathrm{M}$ protein labeled at $39^{\circ} \mathrm{C}$ was assembled into virus particles. This is evidence that the temperature-sensitive mutation of the $t s$ M301(III) virus is a defect in the $M$ protein, as first noted by Lafay (8) for $t s \mathrm{O} 89$ (III).

In cells infected with ts M501(V), the large amount of soluble $M$ protein decreased after the shift to $31^{\circ} \mathrm{C}$, and a higher percentage of this protein was bound to membranes (Table 1). The $G$ protein also underwent a decrease in mobility as a result of the temperature shift, probably a reflection of further glycosylation (not shown). However, only a small amount of viral protein assembled into extracellular virions after the temperature shift, and thus the defect was not very reversible.

The mutant $t s \mathrm{O} 45(\mathrm{~V})$, however, showed a more reversible phenotype as observed by Lafay (8). After the temperature shift, the amount of $M$ bound to membranes increased, and the amount of viral protein in virions showed an eight- to tenfold increase. However, all of the labeled viral proteins were incorporated into virus in approximately the normal ratios, including the $\mathrm{G}$ protein, which is blocked in maturation within the infected cell at $39^{\circ} \mathrm{C}$. This reversible phenotype of the $G$ protein was also observed in the iodination experiments described above.

In cells infected with $t s \mathrm{M} 601$ (VI) the temperature shift allowed an increase of incorporation of labeled proteins into virions. The small amount of $\mathrm{N}$ protein in these cells was not incorporated into virus, but the $M$ and $G$ proteins were. After the shift in temperature to $31^{\circ} \mathrm{C}$ we also observed a decrease in the amount of soluble $\mathbf{M}$ in these cells.
The defect in virion maturation in cells infected with $t s$ G41(IV) was also reversible. After the temperature shift, a large increase in viral protein assembly into extracellular virions occurred. The large amount of $\mathrm{M}$ protein bound to membranes in these cells decreased after the temperature shift, and at least part of this material was incorporated into extracellular virus. Very little of the undegraded $\mathrm{N}$ protein chased out of the cells during this period.

Thus, in many cases the increase in soluble $M$ protein observed in the mutant virus-infected cells at the nonpermissive temperature was reversed by lowering the temperature, and this protein is presumably then incorporated into the membranes of the infected cells and into extracellular particles.

\section{DISCUSSION}

We have utilized temperature-sensitive mutants of VSV in an attempt to define the interrelationships of the viral proteins in the processes of virion morphogenesis. Certain aspects of the separate pathways of maturation of the viral proteins shown schematically in Fig. 6 are apparently independent of the other viral proteins, such as migration of the $G$ protein to the surface of the infected cell. Others, such as binding of the $\mathrm{M}$ protein and nucleocapsid to membranes, are the result of interactions between viral proteins.

Effect of mutations in the glycoprotein. Protease digestion and surface iodination experiments have demonstrated that the G protein of $t s \mathrm{M} 501(\mathrm{~V})$ and $t s \mathrm{O} 45(\mathrm{~V})$ does not mature to the surface of infected cells at the nonpermissive temperature. Also, conversion of $\mathrm{G}$ protein to the sialylated $G_{2}$ form does not occur under nonpermissive conditions. Cell fractionation studies have suggested that the $G$ protein of $t s \mathrm{M} 501(\mathrm{~V})$ may be defective in movement from the rough endoplasmic reticulum (fractions $1+$ 2, Fig. 4). Thus, the lack of addition of the terminal sialic acid may be a result of the inability of the protein to migrate to the proper site in the cell for glycosylation rather than its inability to act as a receptor for the carbohydrate residues. However, some mutant $G$ protein does appear in fractions $5+6$ under nonpermissive conditions, and it is unclear whether this reflects imprecision of the fractionation scheme or true movement into smooth membranes (see reference 5).

The defect of the G protein is inherently interesting because it implies that proteins once inserted into the endoplasmic reticulum are not passively transported by membrane movement to the surface of the cell. Instead, some interac- 


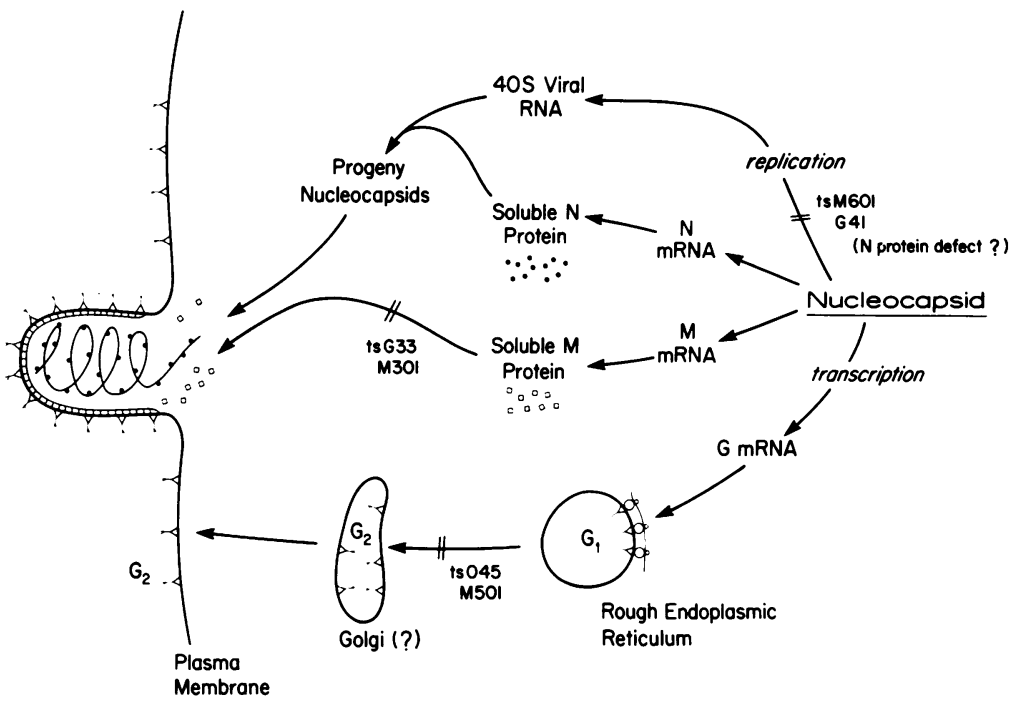

Fig. 6. Schematic diagram illustrating the pathways of maturation of the major structural proteins of $V S V$ and the proposed site of block in virion assembly for certain temperature-sensitive mutants.

tion between the $\mathrm{G}$ protein and cellular structures, possibly transport proteins, must occur. Whatever the defect may actually be, a portion of the $\mathrm{G}$ protein of $t s \mathrm{O} 45$ (V) can move to the surface of the cell once the temperature is lowered, suggesting that the protein can fold to its proper conformation and then mature normally.

Effect of defects in assembly of nucleocapsids. Two mutants that encode a labile $\mathrm{N}$ protein and synthesize little $40 S$ viral RNA at the nonpermissive temperature yielded somewhat different results in terms of the viral protein structures that accumulate in cells infected with these viruses at the nonpermissive temperature. The maturation of the $\mathrm{G}$ protein to plasma membranes appeared to be normal in both cases, and thus there was no evidence for any role of the nucleocapsids in maturation of the $G$ protein. However, in cells infected with ts M601(VI) nearly all of the M protein was soluble, whereas in cells infected with $t s$ G41(IV) a large percentage of the M protein was in membrane-bound structures with intermediate density. These may have been actual intermediates of budding because at least a portion of these structures could be chased into virions after a shift in temperature to $31^{\circ} \mathrm{C}$. The difference between these two situations may be explained by differences in the actual mutations of the viruses. In cells infected with $t s$ M601(VI) there are probably very few nucleocapsids in the cells at any temperature, and under these conditions the M protein may not be able to bind stably to membranes. On the other hand, tsG41(IV) accumulated large amounts of $40 \mathrm{~S}$ RNA at $31^{\circ} \mathrm{C}$, and while allowing synthesis of mRNA at $31^{\circ} \mathrm{C}$ we must be allowing the accumulation of significant amounts of nucleocapsids. These may be capable of binding to membranes with the M protein, but incapable of budding from the cell until the temperature is lowered.

In cells infected with $t s \mathrm{M} 502(\mathrm{~V})$ none of the $\mathrm{N}$ protein is assembled into nucleocapsids. Again, very little of the $\mathrm{M}$ protein is bound to membranes, suggesting that the $\mathbf{M}$ protein cannot form a stable complex on the plasma membrane with only the glycoprotein. This analysis is complicated, however, by the fact that we cannot rule out the possibility of a second mutation in the $\mathrm{G}$ protein suggested by its assignment to complementation group $\mathrm{V}$.

Effect of mutations in the $M$ protein. The $M$ protein in cells infected with $t s$ M301(III) at the nonpermissive temperature is degraded at a rate three- to fourfold faster than the M protein in cells infected with wild-type virus (7). The residual undegraded $t s \mathrm{M} 301$ (III) $\mathrm{M}$ protein is almost exclusively membrane bound, and much of it bands at the density of whole virions. These structures may not be normal budding intermediates because none of the $M$ protein could be chased into virions upon a shift-down to the permissive temperature. Furthermore, protease treatment of intact cells could not remove the membrane-bound $\mathrm{M}$ proteins, and no buds were evident on the cells by electron mi- 
croscopy (unpublished data). We are presently uncertain as to the exact identity of these $\mathbf{M}$ protein-containing structures. The temperature-sensitive lesion, apparently in the M protein, had no effect on the migration of the $G$ protein to the cell surface, and thus there was no evidence for a role of the $M$ protein in the maturation of the $\mathrm{G}$ protein.

\section{ACKNOWLEDGMENTS}

We gratefully acknowledge the technical assistance of Martin Brock.

D.K. was supported by a National Science Foundation predoctoral fellowship during part of this work and a Public Health Service traineeship during the remainder. D.B. is an American Cancer Society research professor. H.F.L. was the recipient of Public Health Service research career development award GM-50175 from the National Institute of General Medical Sciences. This work was supported by Public Health Service grants AI-08814 and AI-08388 from the National Institute of Allergy and Infectious Diseases, American Cancer Society grant E559, and Public Health Service grant CA-12174 from the National Cancer Institute.

\section{LITERATURE CITED}

1. Flamand, A. 1969. Etude des mutants thermosensibles du virus de la stomatite vesiculaire mise en point d'un test de complementation. C.R. Acad. Sci. Paris 268:2305-2308.

2. Flamand, A. 1970. Etude genetiques du virus de la stomatite vesiculaire: clasement de mutants thermosensibles spontanes en groupes de complementation. J. Gen. Virol. 8:187-195.

3. Garoff, H., and K. Simons. 1974. Location of the spike glycoproteins in the Semliki forest virus membrane. Proc. Natl. Acad. Sci. U.S.A. 71:3988-3992.
4. Holloway, A. F., P. K. Y. Wang, and D. V. Cormack. 1970. Isolation and characterization of temperaturesensitive mutants of vesicular stomatitis virus. Virology 42:917-926.

5. Knipe, D. M., D. Baltimore, and H. F. Lodish. 1977. Separate pathways of maturation of the major structural proteins of vesicular stomatitis virus. J. Virol. 21:1128-1139.

6. Knipe, D. M., H. F. Lodish, and D. Baltimore. 1977. Localization of two cellular forms of the vesicular stomatitis viral glycoprotein. J. Virol. 21:1121-1127.

7. Knipe, D., H. F. Lodish, and D. Baltimore. 1977. Analysis of the defects of temperature-sensitive mutants of vesicular stomatitis virus: intracellular degradation of specific viral proteins. J. Virol. 21:1140-1148.

8. Lafay, F. 1974. Envelope proteins of vesicular stomatitis virus: effect of temperature-sensitive mutations in complementation groups III and V. J. Virol. 14:12201228.

9. Ngan, J. S. C., A. F. Holloway, and D. V. Cormack. 1974. Temperature-sensitive mutants of vesicular stomatitis virus: comparison of the in vitro polymerase defects of group I and group IV mutants. J. Virol. 14:765-772.

10. Pringle, C. R. 1970. Genetic characteristics of conditional lethal mutants of vesicular stomatitis virus induced by 5-fluorouracil, 5-azacytidine, and ethyl methane sulfate. J. Virol. 5:559-567.

11. Pringle, C. R. 1970. The induction and genetic characteristics of conditional lethal mutants of vesicular stomatitis virus, p. 567-582. In R. D. Barry and B. W. J. Mahy (ed.), The biology of large RNA viruses. Academic Press Inc., London.

12. Rettenmier, C., R. Dumont, and D. Baltimore. 1975. Screening procedure for complementation-dependent mutants of vesicular stomatitis virus. J. Virol. 15:4149.

13. Unger, J. T., and M. E. Reichmann. 1973. RNA synthesis in temperature-sensitive mutants of vesicular stomatitis virus. J. Virol. 12:570-578. 